\title{
FUNDAMENTAL LEGAL CONCEPTS AS APPLIED IN THE STUDY OF PRIMITIVE LAW
}

\section{E. ADAMSON HOEBEL $\uparrow$}

I.

To date, there has been too scant a recognition of the fertile possibilities in the study of primitive law for the study of law in general. In consequence, the ethnology of law has been to a considerable extent a field of neglected opportunity for the anthropologist and student of law alike. Students of law, enchanted with the intricate mazes of their stately formal garden, have generally looked on the ficld of primitive law.as an undomesticated and infertile wilderness. The prevailing pattern is to deny the existence of law in societies which succeed in stetling disputes and claims without benefit of courts. ${ }^{1}$ This parochial point of view has been to a great extent so successfully impressed upon anthrupologists that only a very few have even attempted to give consideration to the legal materials which might exist in primitive socicties. Inthrupology, as a science, is unequipped with exploratory tools and methunllogical techniques for apprehending and handling the social facts which pertain to law and legal problems in primitive societies. In cunsequence, the science has had little to offer lawmen to date. It is as a monument to this fact that Sir Henry Maine's Ancient Lazo still remains after eight decades the preeminent work on the origin and nature uf primitive legal institutions. This is true even though Maine wrote at a time when knowledge of primitive society was meagre and faulty, to say the least, and Sir Henry was concerned not so much with primitive law as with the "archaic" law of classical antiquity. In view of the tremendus derelopment and accomplishments of modern anthropology in general, this may be dubbed a queer intellectual lag.

In building a sound ethnological jurisprudence it is necessary that we have tools to work with that we may produce valid materials to work upon. The problem rests in the fact that the anthropologist has not been supplied with good, sharp conceptual implements designed ti, handle lawstuff. Without such tools he runs the risk of butching his study of law-ways and judicial activities if he makes so bold as tu run the risk. It follows that few anthropologists have, to date, been inspired

$\doteqdot$ Assistant Professor of Anthropology and Sociology, New York Cniversity.

The author owes a debt of gratitude to Professors Karl N. Llewellyn, Max Radin, A. L. Kroeber, R. H. Lowie, and his colleagues at New Yurk University, Prufessars Cecil Headrick and John McConnell, for critical reading of the manuscript of this artisle.

1. The recent work by SEAGLE. The QuEst for L.aw (1941) offers the current exemplification of the pattern. See cc. II \& IV.

2. First published in 1861. 
to make the try. Exceptions there are, rare craftsmen with an intuitive knack, who have turned in a full-bodied ethnological report of a primitive people's legal behavior, and who have done it without much more than a layman's knowledge of legal concepts. Barton was a school-teacher in Luzon when he did the work that produced the Ifugao Law. ${ }^{3}$ Bruno Gutmann was a missionary in Africa when he made the studies that brought forth Das Recht der Dschagga. ${ }^{4}$ True, Rattray was a lawyer before, as an English colonial administrator, he did the Ashanti ${ }^{6}$ - but he was a case-trained lawyer. This last fact is important. The famous German scholar in the field of ethnological jurisprudence, Professor Joseph Kohler, was also a legalist before turning to ethnology. But his legal background was that of theoretical systematism, and the result of his prodigious efforts is a mountain of ethnological unreality. ${ }^{\circ}$ It is small wonder that the Germans of the Kohler school made little impress on either legal history and analysis or ethnological theory and method. For an exceptional contrast to the Kohler futilities, one may consider Wigmore's studies in primitive Japanese law. ${ }^{7}$ Contemporary with Kohler's earlier writings, Dean Wigmore's studies show the sturdy solidity of a legal method applied to an anthropological problem when that method is devised by a case-trained scholar of the law.

The question whether the law of primitive peoples is "true" law or not, will not be discussed here. Professor Karl Llewellyn and the present author have, in a recently published work, brought legal and anthropological materials to bear upon the study of the Cheyenne Indian ct1ture to demonstrate the worthwhileness of the study of primitive law to effect a better understanding of civilized law. ${ }^{8}$ In an earlier study of the Comanche Indians I suggested an "anthropological definition of law" such as may be warranted by the facts as they exist in literate and non-literate societies alike. ${ }^{9}$

This paper accepts the proposition that such anthropological data as are already collected demonstrate that there is significant legal behavior among primitives: that there is law in primitive societies in the same sense as in ours. The thesis of this paper is that, this being so, the

3. Barton, Ifugao Law (1919), 15 U. Cal. Publ. Am. Arch. \& Etri. No. 1, 1-186; The Half-way Sun (1930) cc. III \& VII; and Philipline Pagans: Thie: Autobiographies of Three Ifugaos (1938).

4. Guthann, Das Recht der Dschagga (1926).

5. Rattray, Ashanti Law and Constitution (1929).

6. See his numerous articles in the Zeitsch. $\mathrm{F}$. Vergleich. Rechtsivissenschist beginning with vol. 3 (1892) to vol. 36 (1919).

7. See Wigmore, Notes on Land Tenure and Local Institutions in Old Japan (1891) 19 Astatic Soc. of Japan 37.

8. Llewellyn \& Hoebel, The Cheyenne Way: Conflict and Case-law in Primitive Jurisprudence (1941).

9. See Hoebel, The Political Organization and Lazereways of the Comanche Indians (1940) Memoir 54, Am. Antr. Assoc., 45-48. 
least common denominator of civilized law is the least common denominator of primitive law. The basic tools of the student of jurisprudence. though originally designed to fit the needs of the student of civilized law, should therefore suitably serve the needs of the student of primitive man. If this be true, then the anthropologist may find some of his touls for the study of primitive law ready-made and well designed in the fundamental legal concepts of modern jurisprudence. It will then hehoove the anthropologist to attain the mastery of these fundamental tools if he is to produce an ethnological jurisprudence that is sround and adequate; and, what is more, the materials will then be communicated in a form that will be meaningful to the student of law.

It is, of course, true that neither courts, nor lawyers, nor jurisprudence have all of them bothered to reduce their technical concepts to clear ant basic fundamentals. For, as Llewellyn so cogently put it, "legal usasce of technical words has sinned, and still does. in two respects; it is involved in ambiguity of two kinds: multiple senses of the same term, and terms too broad to be precise in application to the details of single disputes. . . . No logician worth his salt would stand for it; no scientist would stand for it." 10

Yet it is a happy fact that the essential and fundamental legal concepts have been reduced to simplicity, precision and universality in the system advanced by Wesley Newcombe Hohfeld. Hohfeld, motified, provides at hand a set of accepted instruments which deserve riguruss use in primitive jurisprudence. ${ }^{11}$

10. Llewelly, The Bramble Busi (1930) 83.

11. Professor' Kocourek, one of Hohfeld's most rigorous critics, has recently written: “After Hohfeld's death various attempts were made to subject the Hohfeld furmulation to critical consideration, and in one or two instances the critical findings were unfavorable. On the whole, however, the weight of opinion in America, and perhaps, alc", in England, accepts the Hohfeld formulation as logically currect and as practically useful." The Century of Analytic Iurisprudence Since Jolm Austin (1935) 2 Iaw: A Century of Progress 195, 207.

"With some variation in terms Hohfeld's analysis has found acceptance . . . [it] has been taken over in the pending restatement of the law by the Ameriean Law Insti-

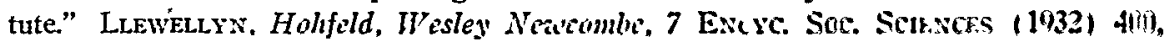
401.

"It professes . . . and, I think, successfully-to be able to reduce any legal trancaetion, however complicated, to its actual constituent elements or atums." Radin, 1 Rcstatement of Holffeld (1938) $51 \mathrm{HARv}$. L. REv. 1141, 1164.

"One of the greatest messages which [Hohifeld] . . . gave to the legal profession was this, that an adequate analytical jurisprudence is an absolutely indispensable tuol in the equipment of the properly trained judge or lawyer-indispensable, that is, for the highest efficiency in the discharge of the daily duties of his profession." Cook, Holffeld's Contributions to the Science of Law (1919) 28 Y.LLE L. I. 721. "He demonstrated its utility by many examples from the law of contracts, turts, ageney, property, etc., showing how the courts are constantly confronted by the necessity of distinguihing between the eight concepts and are all too often confused by the laek of clear comtepts and precise terminology." Id. at 729. 
II.

The Hohfeldian analysis reduces all legal concepts to a minimum of eight. ${ }^{12}$ These eight concepts pair off in mutually interdependent converses so that there are conceived to be but four fundamental legal relations, each representing a reciprocal condition existing between two persons. These relations and the eight concepts are as follows:

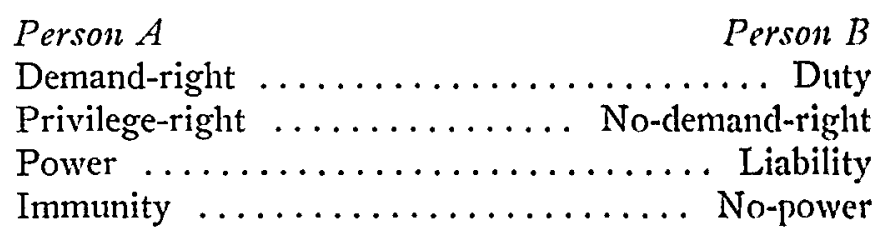

Denand-right means that $A$ has a legal expectation that $B$ behave in a specific way with respect to $A$ (in debt, $B$ must pay $A \$ 100$ : this is $A$ 's demand-right). Duty means that $B$ must behave in a specific way with respect to $A$ (in debt, $B$ must pay $A \$ 100$ : this is $B$ 's duty).

Privilege-right means that $A$ is free to behave in a certain way with respect to $B$ ( $A$ is free, as against $B$, to sell Blackacre to $X, Y, Z$ : this is $A$ 's privilege-right). No-demand-right means that $B$ has no legal redress if $A$ behaves in a certain specific way with respect to $B(A$ is free, as against $B$, to sell Blackacre to $X, Y . Z$ : this is $B$ 's no-demanclright).

Power means that $A$ may voluntarily create a new legal relation affecting $B$ (if $B$ makes an offer, $A$ can close the contract: this is $A$ 's power). Liability means that $B$ is subject to a new legal relation voluntarily created by $A$ (if $B$ makes an offer, $A$ can close the contract: this is $B$ 's liability).

Immminity means that $A$ is not subject to $B$ 's attempt voluntarily to create a new legal relation affecting $A$ (if $B$ "sells" $A$ 's atutomobile, it nevertheless remains $A$ 's auto: this is $A$ 's immunity). No-pozor means that $B$ may not voluntarily create a new legal relation affecting

12. Hohfeld, Some Fundamental Legal Conceptions As Applicd in Judicial Reasoning (1913) 23 Yate L. J. 16; Fundamental Legal Conceptions As Applicd in Judicial Reasoning (1917) 26 YALE L. J. 710. These essays and certain others by Hohfeld were edited by Cook and published in book form: Honfeld, FundsMental Leant Concrin tions As Applied in Judictal Reasoning and Other Legal Essays (1920). For refinements of Hohfeld's concepts see Corbin, Legal Analysis and Terminology (1919) 29 YALE L. J. 163. See Radin, supra note 11 at 1163 : "We may summarize by saying that a restated Hohfeldian analysis may safely discard a great many of the detailed terms that Hohfeld - rather tentatively - used, and even some which he apparently regarded as of high importance. We may even - in fact we must - reject some of the logical relationships he found in these terms . . . But the essentials of Hohfeld's method make a workable scheme." 
$A$ (if $B$ "sells" $A$ 's automobile, it nevertheless remains $A$ 's auto: this is $B$ 's no-power).

In all situations the important thing is never to forget that the leyal relation is identical, whether viewed from the pusition of $A$ or of $B$. The difference lies not in the relation, which is always two-sided, but in the positions and outlook of $A$ and $B$ which together make up the two converses entering into the relation. Thus if the analyst and his readers are to grasp the Hohfeldian relation clearly, and are nut to lue trapped into slips, then the relation must he su stated that the furm of its language does not change one jot whether it expresses .1's relation to $B$ or $B$ 's relation to $A$. This simple principle must net lute neglected.

For primitive law, especially, but also of valid impurtance for general jurisprudence, are two additional points which wught to lue adkled to the Hohfeldian doctrine. First, in any suciety une may expect to find a series of sub-groups which taken together constitute the social Entirety. Every single one of these sub-groups will have its own code of "standards" and "norms" to set the patterns of hehaviur and to control the activities of the members of the group with respect to each other. Some of these standards may be found to have an imperative quality for the membership of the sub-yroup under consideration. They will, then, on the level of that sub-group have a quality which is significantly similar to the "legal". The legal standards, it is generally agreed, apply to the regulation of behaviur of all persons within the social Entirety, and the legal standards supersude the standards of any and all sub-groups, if they are invoked. Many sucial complexities arise, however, from the fact that the individual is at one and the same time a member of sub-groups and of the social Entirety, and his leyal relations on the separate levels of the two orders may be in sharp conflict. To unravel the social (and legal) situation, the analyst must le comsistently aware of the possibilities of non-consistency between the legal relations on the law level and on the sub-group level. A religious conscientious objector whose cult is not recognized by the Selective Service Administration may well illustrate the conflict of duties (in the Hohfeldian sense) imposed by the legal as against the religious intperative. Analogue after analogue will confront the investigator of the primitives. Even within a supposedly well-ordered and consistent civilized legal scheme the same pluralisn is at hand to raise hob. When Hohfeld "annihilated the classic theory that there was no conflict between law and equity"13 he had to worry over the problem of co-systems of "law" involving the same persons. Hohfeld had to wrestle with the very" problem of the hierarchy of imperatives to which I have called attention. is

13. SEAGLE, op. cit. supra note 1 , at 400.

14. A much more thorough-going discussion of this phenumenon of divere levels of law and sub-group patterns of interpersonal relatiuns is developed in Luwweur:: $\&$ 
The second additional point to which attention may well be called is that Hohfeldis four fundamental legal relations are reducible into two further categories. They are either active (positive) or passive (negative). Consideration of functions will show that the demancl-right, dity and the power, liability relations are active. On the strictly legal level they are imperative relations subject to the coercive authority of the courts and other recognized law-enforcing agencies.

The privilege-right, no-demand-right and the immunity, no-power relations are passive. They are not in themselves subject to direct legal enforcement. Rather, they set the limits of the law's activities, for they do no more than define the types of behavior which the law itself declares to be outside the scope of its sphere of control. Here the law hems itself within the boundaries of its own concentration camp- often, however, for positive purposes. Thus, civil liberties, though formally negating law's interventions, serve positive purposes in the legal system which "protects" them by negating legal interference.

If we speak of these passive relations as legal relations (as is customary), it is then only in the sense that our legal systems must malkc declaratory decisions as to when specific forms of behavior fall into the passive privilege-right, no-demand-right and the immunity, no-power relations. Because, under our prevailing system, the majority of these decisions are made by legal agencies, we are prone to call them "legall". This leads to the common phrasing, "The Law is that $A$ can scll Blackacre to $X, Y, Z$," which is not quite right. An accurate phrasing would have to be, "The Law says that $A$ can sell Blackacre to $X, Y, Z$." Or if one is to be accurately precise, as is imperative in legal and sociological analysis, the statement should read, "The Law declares it is none of its direct concern if $A$ sells Blackacre to $X, Y, Z$." This distinction is of vital importance, and it is much more than a matter of mere wordage. It clarifies the relations of the individuals with respect to the law and each other. When so put, no one will fail to recognize that the passive legal relations are statements of "no-law."

For the study of primitive law this is especially important; it will aid in clispelling the illusion that law and custom are one among primitives. In our legal system every demand-right that $A$ has upon $B$ is buttressed by accompanying demand-rights upon courts that they compel $B$ to perform his duty. In primitive society it may also be that there are courts towards which $A$ may have demand-rights in the event another person violates his legal rights; this is the case when a system of "pulblic" law exists. But more commonly, there are no courts and no specialized law-enforcing agents. It will frequently happen that the aggrieved

HoEBEL, op. cit. supra note 9, especially cc. VIII \& XI. See also Llewellyn, Thic Normative, the Legal, and the Lazv-Jobs: The Problem of Juristic Method (1940) 49 YALE L. J. 1355. 
person himself, or his kinsmen, must enfurce the individual's demandrights. If they do this in a socially recognized and generally accepted manner, they have the legal privilege-right to apply the regular sanctions. The difference, then, is this: in our system, a failure to meet a demandright by one party engenders a series of further demand-rights by the aggrieved on the courts and law-enforcing agents that they complel performance, or impose penalties; in primitive systems of "private" law, a failure to meet a demand-right by one party engenders a privilegeright in the aggrieved and his kin to compel performance, or impuse penalties, in a regularized manner.

\section{III.}

The most effective test of the usefulness of the Hohfeldian fundamental legal concepts would be to apply the system of analysis to the most vexatious problems of primitive law-the drawing of the real shape of institutions said to be "communistic" as against "private", or to be "corporeal" as against "incorporeal". These simple, all-embracing words cover legal and social complexes; they are not fundamentals in themselves, and they easily become unsatisfactory substitutes for clear analysis of the often exceedingly complex niceties of primitive legal institutions. Nuch acrimonious argumentation can effectively be made unnecessary by accurate and precise analysis, leaving the catch-all labels to the political protagonist. They have no place in the social science of comparative jurisprudence.

To this end, materials from the Yurok Indians of northern California may be properly scrutinized with profit. The Turoks are well known ethnologically by virtue of the published works of Professor Kroeher, whose writings also include some brief formal statements of Yurok law. ${ }^{15}$

The Yuroks live along the lower reaches of the Klamath River and the adjacent shores of the Pacific Coast where they subsist as a primitive fishing and food-gathering people. ${ }^{16}$ Their world is a precise little affair, a nicely knit cocoon which hems the Yuroks within the confines of their river valley and a short stretch of the sea coast. They refuse to believe

15. Kroeber, Handbook of the Indians of California (1925) Smrrusonn: IsstrtUte, Bureau of AMr. Ethnology, Bull. 78, p. 20: l'trok Las' (1922) 22 Irt. Corit. of AMTERTCANists 511.

16. Although the present tense is used in the description of the lurels, reference is to usages such as prevailed up to the beginning of the present century. Social and economic adjustments to the impact of American civilization have, of ciurse, wrought changes in Yurok life. In the field of law the Yuroks are now subject to the laws of the State of California and of the Federal Government. The prublem of "cunflict of laws" as between the Yurok system, which still functions in part, and the state and federal systems as they impinge upon the Yuroks would be an interesting scparate study. 
that there is a world beyond these limits, and within their known country they define all iclentifiable geographical places with names and attributes according to a traditional pattern. This is but one phase of a marked conservative-mindedness and interest in status definition of all things and persons. It may be expected, in view of their marked concern with personal status, that, though the Yuroks have no formal government, they will nevertheless exhibit a welter of legal relationships in the realm of personal law.

Wealth, its accumulation and display, is an interest of the greatest vitality for these people; tokens of wealth are strings of dentalium shell, woodpecker scalps, and large ceremonial obsidian blades. There is symbolic wealth in consumable goods, as well, but prestige comes from the goods whose value is largely fiduciary. Property is therefore of extreme importance as an instrument for the maintenance of personal status and prestige.

In this setting every person, except bastards and slaves, hats a full quiver of demand-rights, privilege-rights, powers, and immunities which he fits to his litigious bow on the slightest provocation. Though there is no specialized law-enforcing personnel among the Yuroks, there is nevertheless a regularized procedural technique for enforcing conformance to the accepted legal standards. Enforcement is attaincel through the imposition and collection of damages, or by the infliction of bodily injury - even death - to the offender, for, as Kroeber has rightly observed, "In the last analysis, violence to the body is the legal force [imperative]."17 It is up to the aggrieved and his kinsmen to institute the proceedings, as is usual in the private law of primitives, but thcy do not themselves, in the case of the Yuroks, arraign the offender or determine the extent of the damages to be assessed. This is done by an informal court of go-betweens, or "crossers", who are chosen from among non-relatives living in different communities from those of the parties to the litigation. The plaintiff names two to four such persons, and the defendant does likewise. Whatever these men decide will be the judgment in the case. The crossers obtain evidence from the disputants and any other available sources; they confer among themselves as to what rules of substantive law apply, if any, to the case in hand; they arrive at a verdict and then, if they have found him guilty, declare an explicit judgment against the defendant. Thus, when the crossers find against the defendant, they sustain the plaintiff's claim as a valid demand-right, for the defendant has been found derelict in his duty; the judgment assesses him with customary damages which must be paid to the plaintiff. In default, the defendant must become the plaintiff's debtor-slave, or his execution by the plaintiff and his kin will be war-

17. In seminar discussion, see note 18 infra. 
ranted. There is risk in this of engendering a feud, though public apinion will support the plaintiff in his action. Each side fees his crossers with a dentalium shell, a fee which is euphemistically known as "his murcassin"! It literally compensates for the footwork involverl in adjudicating the case.

In fixing damages, the crossers are guided by well-established principles of value. Except for the above-mentioned hastards and slares, who have no legab rights, every person has a fixed and immutalle wergild, every material object its fixed worth determined lyy what has been paid for it in previous economic transactions, and every intangihle property-right has its customarily recognized valuation. Bricle-purchase, which alone makes a marriage valid, determines wergild, for the lasa of a person is the equivalent of what one's father paid for his wifethat person's mother. Bastards have no wergild for the simple reasin that no bride-price was paid for their mothers. In conserquence, they have no legal status whatever. This fact is true in theory and in practice, for such persons have no father's kin to support them, while their mother's kin are ashamed to come forward for them. In addition to being legally without laga, they are social pariahs, a living affront to the Yurok sensibilities of social decency.

Injury to the person is scaled in accordance with the seriousness of the trespass and the wergild evaluation of the aggrieved. Legal relations of many interesting sorts enter into the law of persons. I few examples put into Hohfeldian terms will be to the point. ${ }^{18}$

The first case arises out of the broad conception of contributory negligence held by the Yuroks. The first factor is that locations which are most favorable as fishing sites along the hanks of the Klamath river are subject to private ownership. The holder of the hereditary title to a fishing spot enjoys, as against any other person, the privilegeright to exclusive use of the location. He possesses the power, however, to extend a temporary privilege-right to any second party to fish from his private locus. Extension of such a privilege-right to a stranger carries with it a duty on the part of the owner to see that no injury befalls his guest. Failure to do so is held by the Yuroks to be negligence; should the guest have the misfortune to slip on a rock while fishing from his host's territory, suffering injury thereby, he has a legitimate demand-right for damages against his host arising out of his original demand-right that the owner protect him from injury.

In a similar vein, Kroeber recorded a case in which a visitor to three brothers went sea-lion hunting while he was yet their guest. The venture

18. All the Yurok case materials to follow were presented hy Professor Froeber in his discussion of Yurok culture before the joint seminar (anthropology and psychology) on Psychological Approaihes to Culture, The University of California, in the efrring of 1941. 
ended disastrously; he drowned. The dead man's kin demanded damages equivalent to the full homicide wergild. The three brothers denied the claim as invalid, refusing thereby to acknowledge a duty. Crossers were then selected to take testimony, state the law, and give judgment. Testimony established evidence that the brothers had invited the deceased to stay overnight with them. In Yurok law this imposed a duty to safeguard the well-being of their guest. It was further established that the drowning occurred offshore from the very beach which was privately owned by the three brothers. This was held to impose a parallel duty to safeguard the guest. The brothers were judged guilty of negligence on these two counts, and the crossers awarded full wergild to the kin of the deceased.

Land ownership involves not only powers and privilege-riglits for the title holder, but unique and interesting duties as well. Another case, recorded by Kroeber as having occurred some eighty years ago, reveals further aspects of Yurok legal relations with respect to property. In this instance, the family of which $M$ was headman did not own the beach as such but possessed the long-established demand-right that the flippers of all sea lions caught along the Pacific coast for a distance of about four miles in either direction from their settlement be given to them. A hunter, named $L$, disregarded his duty in this relation on several occasions. $M$, instead of taking legal steps, brooded, and finally assaulted the father of $L$, wounding him with an arrow. The family of $L$ took action for assault-damages. Crossers handled the case in the regular manner. Their verdict was that the damages sustained by virtue of the wounding were slightly less than the damages arising from the violation of the $M$ family's demand-right for the sea-lion flippers. Ergo, the $L$ family's claim was nullified. The affair was thus res judicata; but, though adjudicated, the sense of grievance was not washed out. As so often happens, when legalism outweighs juristic method, the law served only its standards and did not deal with the social problem. ${ }^{10}$ Thus, $L$ nursed his sense of grievance, and, two days after the legal settlement, he cursed $M$. To lay a curse is prohibited by I Irok law, and on this basis $M$ entered a claim for damages against $L$ for violation of his duty to refrain from cursing. Crossers were at work on the case when hotheaded relatives of $M$ murdered $L$. The sister of $L$ cursed the killers, and this time it was her privilege-right to retaliate. But with greater effect $L$ 's mother entered a claim to have transferred to her the hereditary demand-right on sea-lion flippers as equivalent to her son's wergild. She won the award.

The examples thus far presented are thought to show two things. First, that the presentation of primitive material by way of the Hoh-

19. Sec Llewellyn \& Hoebel, op. cit. supra note 8, at 45. 
feldian concepts is feasible. Second, and better, that such presentation sharpens perception of the cases, the issues, and their more precise bearings and limits in law.

The demonstration of a third point may now be attempted: that unnecessary controversy and confusion engendered by the use of lalsels which are over-broad or inapplicable may be avoided by substitution of Hohfeldian analysis.

One of the fields of skirmish between the collectivist and the individualistically-minded anthropologists has been the identificatiun of certain primitive property forms as either "private" or "communal". I Legal writers have also entered into the fray, as for instance the recent castigation of Bronislaw Malinowski by William Seagle, with the assertion that Professor Malinowski is guilty of attacking primitive communism "with evidence from a communistic people." undertook to demonstrate that canoe ownership in Melanesia is not the subject of common ownership, as had been maintained by the late English anthropologist, W. H. R. Rivers. ${ }^{21}$ In his famous study of law in the Trobriand Islands, Malinowski takes pains to show that Trobriand canue ownership, as an exemplification of Melanesian practices, is certainly not communism, but an intricate complex of individual "duties, privileges and benefits." "22 Malinowski was completely right in his conclusions that "ownership . . . can be defined neither by such words as "communism', nor 'individualism', nor by reference to 'joint-stock company' system or 'personal enterprise', but by the concrete facts and conditions of use. It is the sum of duties, privileges and mutualities which bind the joint owners to the object and to each other." ${ }^{23}$ In this he is very close to the Hohfeldian type of thinking and terminology. It seems likely that if his case had been put explicitly in Hohfeldian fundamental terms, his comprehensive grasp of the nature of property forms in primitive Melanesian society could not be grossly misconstrued, especially not by a student of law. For if a complex legal and social institution is reduced in clarity to its fundamental components, the vagary of gross catch-all concepts is banished. Confusion and uscless argumentation go out with the catch-alls, for it is in the periphery of their fuzzy boundaries that all the fighting occurs.

Thus, as the Yurok materials are given further consideration, the question of canoe ownership among this people is best handled without reference to communism or private property. A Yurok boat-owner nominally "owns" his boat, but "ownership", as always, is a compound especially of demand-right, duty and privilege-right, no-demand-right

20. SEAGLE, op. cit. supra note 1 , at 53 .

21. Rrvers, Soctal Organization (1924) 10G-07.

22. Malinowski. Crime and Custoas in Savage Society (1920) 17-21.

23. Id. at 20-21. 
relations. The "owner" has a series of demand-rights against any other person that such other person not molest or damage his boat. He has the privilege-right against any other person to use it upon the public. waters and a general immunity from obligation by way of mere offers to buy, though he has the power to sell it or bestow it as a gift. These' are all marks of private ownership. (Such an immunity, however, is not enjoyed in every primitive culture, especially where exchange operates chiefly by "gift" and "return-gift". $)^{24}$ Yet he is also subject to a series of well-recognized duties which certainly limit his exclusive prea rogative over the object. For one thing, he is under a duty to respond to the demand-right of any cross-country traveller that the canoe-owner ferry him across the river when called upon. Failure to do so gives rise to a demand-right for damages on the part of the traveller. Damages equal one dentalium shell. However, in balance with this duty of the canoe-owner - and in direct contrast with the situation where an owner's guest is concerned - it is the passenger's duty to assume responsibility for any injury suffered by the owner in consequence of service he is rendering. In consequence of this, a boat-owner whose house took fire and burned while he was engaged in ferrying a passenger, enjoyed a demand-right for full damages to be paid by his passenger. ${ }^{25}$

Our analysis of these examples from primitive societies leads us to concur with Professor Cook's admirable formulation of the nature of ownership as based on Roman and Anglo-American law. It would seem that the following statement from Cook is aptly tailored to suit the data we have been just analyzing:

"The assertion that a person owns an object is a summary way of stating that he has an exceedingly complex aggregate of legal rights which relate to the object, and indirectly that all the facts necessary to give him these rights exist. This may be expressed by saying that the word ownership denotes such an aggregate of rights and connotes the existence of the facts which give rise to the rights. When the aggregate of rights denoted by ownership is analyzed, it is found to consist not only of an indefinite number of rights in the strict sense or claims available against an indefinite number of persons, each of whom is under a corresponding duty, but also of a large and indefinite number of privileges, powers and immunities, in the senses in which these terms are employed in the system of Hohfeld. The number of such claims, privileges, powers and immunities changes consistently as persons are born, become old enough to owe legal duties and die; they may vary also with the occurrence of other events." 26

24. See Wardle, Gifts, Primitive 6 Encyc. Soc. Scrences (1931) 657.

25. See Kroeber, supra note 15 , at 35 .

26. Cook, Ozmership and Possession (1933) 11 Encyc. Soc. Scrences (1933) 521. 
With such conceptions in mind it is not difficult to deal with the question of the existence of incorporeal property in primitive socicty, as well as tangible chattels. This subject first received anthropological attention in the writings of Professor Lowie, ${ }^{2 \pi}$ who contends that the notion of legal historians that incorporeal property is the result of advanced legal sophistication is a rationalistic prejudice belied by the data from primitive societies.

Professor Lowie's interpretation of certain Irimitive data as evidence of the existence of incorporeal property rights among primitives has also been sharply challenged by Seagle. ${ }^{28}$ Seagle denies that the incorporeal rights of primitives are property in any sense, "the concept of 'possession' rather than ownership is far more suitable in describing the primitive institution." ${ }^{29}$ The rights in question, as he sees them, are not property, because they are no more than extensions of the person; they are a part of the person and hence cannot be properties in the legal sense. Seagle contends on these grounds that "it remains true to say that early law is hostile to incorporeal rights." 10

We may apply the Hohfeldian analysis as a precipitant for these muddy waters. Taking the concept of ownership made explicit in the words of Cook, may we not usefully say that property is any object, tangible or intangible, which is the subject of uwnership? Now pick up the examples of incorporeal property advanced by Lowie and see if they may be properly treated as objects of ownership.

An Andaman Islander composes a song for the uccasion of a tribal gathering, a song that is received with applause. Irrespective of its popularity no one dares sing it except the composer himself. ${ }^{31}$ We are not told what happens in the event someone presumes to sing the song of another, and, in consequence, it is impossible to know on just what level of social control the incorporeal right to songs among the Andamanest exists.

Among the further examples set forth by Professor Luwie is the private ownership of songs, incantations, prayers, and magical formulas. Yerbal patterns of supernatural importance are subject to sale and gift. The owner in some of the instances cited may cumpletely alienate his property, or may sell or give no more than a limited interest in it, retaining the right to use the song or formula while extending a similar right to the recipient.

27. Lowie, Incorporeal Property in Prinuitice Socicty (1923) 37 Yale L. J. 551, and in his Priastrtve Soctety (1920) at 235-43.

28. Seagle, op. cit. silpra note 1 , at 50-54.

29. Id. at 51 .

30. Id. at 52 .

31. Lowie, Prmitive Society (1920) 236. 
So long, of course, as any other aspects there may be are not artificially eliminated from notice, there is no evidence at hand of any legal procedures for setting a legal claim against usturpers of incorporeal property rights of this order just described. There is no evidence that damages are claimed or that punitive penalties may be imposed by the aggrieved or that they will be imposed by any representative of the society or that they are ever the subject of litigation in primitive courts of law. On this point, however, the negative evidence is hardly impressive, unless such evidence has first been expressly sought, becausc the little extant data concerning the actual subjects of litigation in primitive disputes have been to date for the most part ctlled without special inquiry. What we do learn and know is that trespass on these incorporeal rights of a supernatural nature brings supernatural punishments in its train. The sanctions protecting these forms of rights are apparently magico-religious rather than strictly legal. Yet the beauty of Hohfeldian analysis, and this is not yet realized in social and legal science, is that the Hohfeldian relationships can be used to make other-than-legal social relationships clear. ${ }^{82}$

Thus, consider the case of a Plains Indian visionary who has fasted - and sought supernatural power. A bear appeared to him in a dream; it spoke to him and taught him four new songs. It also instructed him in the preparation of a rawhide shield to be painted with a bear symbol and other devices. The bear in the vision also instructed his tutelary that a shield made in accordance with the instructions provides immunity in battle if the four songs are sung before an engagement begins. The visionary has made a shield as instructed; he has sung the songs; his comrades have heard the words; and he has deliberately exposed himself to the missiles of the enemy, coming through unscathed. The value of the shield and the songs has been publicly demonstrated. The shield, as Professor Lowie has made clear, is a material object which is clearly personal property. But the shield as such, in the culture of the Plains Indians, is of little value. What is of value in conjunction with the shield are the songs and the mystic power which the two engender together. The incorporeal property is the thing of worth. The complex of shield, song, and power may be transferred as a gift to son, nephew, brother or friend (in at least one Comanche case which I recorded, ${ }^{33}$ the transfer had to be followed by a vision on the part of the recipient before the mystic power would become operative, however, and this may frequently be the case among other tribes). Or, this same complex may be sold in a commercial transaction which has the qualities of contractual

32. I am indebted to Karl Llewellyn for initial elucidation of this point in discussion and conversation.

33. See Hoebel, supra note 9, at 860 . 
sale. In either case, the recipient may use the complex, if he has properly acquired the rights through regularized transfer, but not otherwise. The consequence of unauthorized use of the shicld and songs is that the usurper will most certainly be killed by enemy missiles, due to the punitive action of the supernatural power. But there is no reason to helieve that the true owner may not recover the shield, if it is stulen, and with it his enjoyment of the songs.

In Hohfeldian terms, all this means simply that the owner of a vision complex can sing its songs and possess its distinctive paraphernalia, and others cannot: this is his privilege-right against any uther person. Frum the standpoint of other warriors in the tribe it means that $A$ alnne can sing its songs and possess its distinctive paraphernalia, and $B$ (or any other person) cannot: this is $B^{\prime}$ 's duty. But $B^{\prime}$ s duty does not give grounds for a legal claim on $A$ 's part in the event of violation; rather, $B$ 's duty exists with respect to the supernatural order, not the sucietal (legal). This form of statement assumes the supernatural [mwers to, be no part of the legal order. But the fact is, in many primitive cultures they can more properly be viewed as sanctioning officials, aperating, so to speak, in "equity" when the "common law" of the secular gives no remedy, or even is supposed not to. If we git further, we can say that $A$ can give away the entire complex; this is $A$ 's power. Suppuse $A$ is free, as against his family, to give it to a non-relative; his son, $x$, cannot prevent him from so doing; this is $X$ 's no-power. $B$ offers to give three horses for the complex. A can close the deal; this is $A$ : power. Again, $B$ offers to give three horses for the complex. $A$ can close this deal : this is $B$ 's liability. Further, $B$ offers three horses for the complex; $A$ can reject the offer: this is $A$ 's immunity. Or, again with respect to this offer and $A$ 's rejection of it: this is $B^{\prime}$ s mo-pnwer. But in some cultures (c.g., the Cheyenne) $A$ cannot well he said to be free to reject the offer. In such a culture $A$ hrolds the cumplex with power in various other persons to force him to alienation ly such an ofter. His "ownership" is accompanied by liabilities to involuntary alienation.

Do we not have here a sufficiently large aggregate of rights denoted by ownership "[which consists] not only of an indefinite number of rights in the strict sense or claims available against an indefinite number of persons, each of whom is under a corresponding duty, but also a large and indefinite number of privileges, powers and immunities . . .," so that one may properly speak of incorporeal property in these matters?

An Hohfeldian analysis makes this unambiguously clear. And, lest the reader fail to note it, he should observe that the Hohfeldian analysis has just been used in the exposition of a social institution which turns out to be not even a "legal" institution (according to the ideas of 
the orthodox). This is possible because Hohfeld's fundamental concepts are more universal than even their inventor himself realized. They fit not only the fundamental legal relations, but also the fundamentals of any complex of imperative social reciprocity. Thus, even were we to grant that a social relation must be recognized by courts and enforced by political agents to be legal, even though we were to accept the idea that social relations enforced by supernatural sanctions are not primarily legal, still, the Hohfeldian system may be applicable to a uscful classification of such an other-than-legal complex as incorporeal property among primitives.

Above all, in the use of Hohfeldian fundamental concepts, for lawyer and anthropologist alike, "thinking thus, in nicer terms, with nicer tools of thought, you pull the issue into clarity . . . unambiguously, becaluse your terms are not ambiguous." 34

It is submitted, then, that here are tools for the anthropologist to use when once he has assembled his body of case materials; for the study of primitive law, like that of the common law, must draw its generalizations from particulars, which are cases, cases and more cases - cases to be dissected and analyzed into their principles. Dissecting tools are needed for the job, whatever type of law system is being studied, for as the late Justice Cardozo counselled, "Cases do not unfold themselves for the asking. They yield up their kernel slowly and painfully." 35 "We do not pick our rules of law full blossomed from the trees." 36 But the yield is rich, and can be much richer, even in the primitive ficld, and the investigation of primitive law need not be too painful if there be sound techniques with which to handle the materials.

34. Llewellyn, op. cit. supra notc 11 , at 88.

35. Cardozo, The Nature of the Judicial Process (1921) 29.

36. Id. at 103. 